IJMS 24 (1), 73-90 (2017)

\title{
ESTIMATING THE DETERMINANTS OF VEHICLE LOAN DEFAULT IN MALAYSIA: AN EXPLORATORY STUDY
}

\author{
LIM HOCK-EAM \\ SIEW GOH YEOK \\ School of Economics, Finance and Banking \\ Universiti Utara Malaysia
}

\begin{abstract}
As revealed by Malaysia's bankruptcy statistics, around a quarter of bankruptcy in Malaysia is due to default of vehicle loan. This has led to the tightening up of vehicle loan underwriting and increased vehicle loan rejection rates. The need for a better credit risk scoring model is also raised by the banks. This warrants a study to estimate the determinants of vehicle loan default in Malaysia. This paper estimates the determinants of vehicle loan default probability which could be used to build a loan default prediction or forecasting model for credit risk scoring purposes. Using a simple random sample of 138 car loan borrowers that was provided by an established bank in Malaysia, the descriptive statistical procedures and econometrics modelling were performed to unveil these vehicle loan default determinants. Results of descriptive statistics revealed that more than half of the borrowers were default. Results of logit models further revealed that loan related characteristics are the most important determinants of probability of default. Specifically, the significant determinants of loan default were: areas of residence, vehicle purchase price, length of service, existing relationship with bank, interest rate, and available guarantor. Borrowers who are in high risk of default are characteristically those who reside in rural areas, secure higher vehicle purchase price, have longer length of employment service, are borrowers new to the bank, acquire loans charged with high interest rates, and are without a guarantor.
\end{abstract}

Keywords: Loan default; Vehicle loan; Logit model; Forecasting model.

Received: 12/4/2017 Revise: 13/5/2017 Accepted: 15/5/2017 Publish: 27/07/2017

\section{Introduction}

Estimating the determinants of a loan applicant's probability of default is very crucial for a bank. The probability of default indicates 
the ability of the loan borrower to fulfil repayments in the future. An inaccurate prediction of loan default will lead to a wrong approval of loan and consequently becomes a non-performing loan. Thus, it is not surprising at all that predicting or estimating the determinants of loan default probability is one of the main study focuses in finance and banking (Gurny \& Gurny, 2013). This is of particular importance to Malaysia which is a high household debt country, amounting to a total of $86.8 \%$ of its Gross Domestic Product since the 2000s (Halim, 2014).

However, borrowing is reported to be less common in Malaysia than the developed countries, such as US; during any given 12-month period, around $11 \%$ of Malaysians aged more than 18 years have taken loans from financial institutions and $12 \%$ of them have a credit card, as compared to $20 \%$ and $62 \%$ in the US, respectively ("Credit-Scoring firms", 2014). Meanwhile, it was reported that a substantial portion of loan applicants, including vehicle loans, are denied due to the concern of default, and Malaysian banks are keen to have a better and reliable credit score tool ("Credit-Scoring firms", 2014).

In Malaysia, CCRIS (Central Credit Reference Information System), a computerised database provided by the BNM (Central Bank of Malaysia), is one of the tools used by banks for calculating credit risk scores. CCRIS report provides three major categories of information; outstanding loans, special attention accounts, and credit facility applications made in the past one year ("Everything you should", 2014). This information is used to generate a credit report to help evaluate the loan for approval and determine the interest rate charged. Nevertheless, even with the CCRIS, statistics revealed that loan defaults, in particular car loans, are still prevalent at an alarming level.

Meanwhile, Selvarani (2011) reported that the number of bankruptcy cases is increasing and a quarter of these (or 105,519 people) are due to defaulting car loans. In order to lower the risk of bad debts, banks are reported to have tighten up their loan application process and are rejecting almost $60 \%$ of car loan applications (Kong, 2014). This high loan rejection rate will have an impact not only on the banking industry but also the growth of the Malaysian automobile industry. Moreover, previous studies showed that efficient bank financing is necessary to achieve sustainable economic growth in Malaysia (Tang, 2003).

Thus, this warrants a study on estimating the determinants of default probability among existing car loan holders (who have been 
screened and passed the risk scoring of the bank and CCRIS). The determinants could be used to build a car loan default prediction model. This prediction model could serve as a supplement to existing credit scoring models and CCRIS. In this context, the importance of estimating the determinants of probability in car loan default cases is clearly demonstrated. Thus, the aim of the present paper is to estimate the determinants of probability of default using a sample of car loan borrowers from an established bank in Malaysia.

In the literature, there are numerous studies on estimating the determinants of a loan default (Tanninen, 2013). Consistent with the "ability to pay" theory of default, various studies found that repayment burden or repayment ability related variables are one of the major determinants of loan default (Alfaro \& Gallardo, 2012). In Malaysia, the repayment burden of a loan is currently measured by the net disposal income ${ }^{1}$, which is used to pay loan instalments. The Central Bank of Malaysia recommends that for loan applicants with repayment burden score of $60 \%$ and above, their application should be rejected. Thus, in the present study that used a sample of existing loan borrowers, it is expected that the repayment burden might not be a significant determinant because almost all borrowers in the sample have a repayment burden score of below $60 \%$. In addition to repayment burden, other potential financial related determinants also had been identified by previous studies, such as income and income related variables (Alfaro \& Gallardo, 2012; Awotwi, 2011).

In terms of socio-demographic variables, previous studies identified that potential determinants of loan default include marital status, age, gender, and level of education. Specifically, a borrower who is married, older, female, and with higher education are found to be less likely to default (Alfaro \& Gallardo, 2012; Avery, Calem, \& Canner, 2004; Sharma \& Zeller, 1997; Stavins, 2000). This finding is not surprising as the socio-demographic variables could represent the underlying factors of tastes, preferences, productivity, and ability. Nevertheless, it is important to note that there are also a few contradictory studies which found the insignificance of socio-demographic variables, such as Okumu, Mwalili, and Mwita (2012) who found that gender has no explanatory power on the probability of default.

Moreover, the loan related variables were also found to be the significant determinants of loan default, in particular, LTV (loanto-value) was revealed to be the most significant determinant and

1 However, in this sample, the banks use gross income instead of net disposable income. 
positively correlated with the probability of loan default (Goriunov \& Venzhyk, 2007; Tanninen, 2013). In addition, Tanninen (2013) discovered that the relationship between borrower and lender explains significantly the probability of loan default. The other determinants found significant by previous studies include: age, amount of loan, length of service, and interest rate (Alfaro \& Gallardo, 2012; Awotwi, 2011; Horkko, 2010; Okumu, Mwalili, \& Mwita., 2012). In short, previous studies recommended the potential determinants of a car loan default and these variables were taken into consideration for the present study. However, in the context of Malaysia, car loan default is largely ignored in literature. This is likely due to difficulty in obtaining data from the banks because from the author's experience, banks in Malaysia are reluctant to share their internal data with researchers.

The present study contributed to the literature by estimating the determinants of car loan default using individual level data from banks, instead of survey data that might subject to bias. Using econometric modelling, the study ascertained that loan related characteristics are the major determinants of car loan default for Malaysian loan borrowers. The present study complemented previous studies of car loan default by providing the case of Malaysia.

\section{Data and Methodology}

\section{Data}

The targeted population of the present study was the car loan borrowers in Malaysia. An established bank ${ }^{2}$ in Malaysia which was willing to provide car loan borrowers' information was selected. Since the car loans provided by the banking sector in Malaysia is quite homogenous, even with data from only one bank, it should have at least an acceptable level of representativeness for the car loan borrowers of other banks in Malaysia. The data were provided by the bank and thus, for the present study, the data could be considered as secondary data (at the individual level).

2 The researchers were not able to provide the name of bank and number of branches on the grounds of confidentiality. However, this should not affect the results of the present study. Moreover, this is the only bank willing to provide information for the present study. This bank is an established bank because it is a licensed financial institution (local ownership) under the Central Bank of Malaysia (see http://www. bnm.gov.my/index.php?ch=li\&cat=banking\&type $=C B \& f u n d=0 \& c u=0)$. The establishment of this bank in Malaysia could be traced back to more than 30 years. 
The bank did not reveal the whole list of its borrowers to the researchers. Instead the bank had randomly selected 138 car loan borrowers from its various branches in Peninsular Malaysia, between January to February 2015. There were no private or other information that could lead to the identification of the car loan borrowers or the branches. The information provided by the bank included: sociodemographics, loan particulars, vehicle particulars, and financial ability characteristics.

Using the bank's criteria, the loan default (dependent variable) was defined as defaulted for two or more monthly instalments. The independent variables were age, marital status, ethnicity, length and areas of current residence, vehicle related variables (price, ownership, types, condition, and capacity), financial ability related variables (house ownership, length, status and sector of current employment, income, other loan, and repayment ratio), and loan related variables (amount, tenure, interest charged, instalment, and availability of guarantor). Descriptive statistics of these variables are presented in the following section.

This sample is unique from two aspects. Firstly, the data were extracted from the authority's record, instead of soliciting from borrowers. Hence, the measurement of variables, especially loan default and income related variables, should be objective and free from bias. Secondly, it is a simple random sample which was drawn by the bank, thus it should have a minimum level of representativeness for the car loan borrowers of the bank. Since vehicle loans offered by the various banks in Malaysia are quite homogenous, this sample could also have a minimum level of representativeness for the population of car loan borrowers in Malaysia.

\section{Methodology}

It was assumed that for each borrower, there is a latent variable that represents his or her tendency to be default in his or her car loan. This loan default tendency is associated with the socio-demographic, vehicle, financial ability, and loan characteristics $\left(x_{i}\right)$. Let $y^{*}$ represent this latent variable and assume that $y^{*}$ is a linear function of $x_{i^{\prime}}$, then, the following can be obtained:

$$
y_{i}^{*}=\sum_{i=1}^{n} \beta x_{i}+u_{i}
$$


IJMS 24 (1), 73-90 (2017)

where

$$
\begin{aligned}
& y^{*}=\text { the unobserved tendency to be overeducated } \\
& x=\text { the characteristics' variables } \\
& u=\text { the error term }
\end{aligned}
$$

If $y$ is the random variable that represents the observed outcomes, $j$, of the borrower, where $j=1$ if default, $j=0$ if otherwise. Assume that the error term follows a logistic distribution, then the logit model can be obtained. The model was estimated using maximum likelihood method with robust standard error.

\section{Analysis and Results}

\section{Descriptive statistics}

Table 1 presents the loan status of the sample. Among the 138 respondents, more than half of them are default. This showed that even with the initial risk screening, including using the CCRIS report, there was still a substantial percentage of default.

Table 1

Loan default status

\begin{tabular}{lcc}
\hline Default & Freq. & $\%$ \\
\hline No & 63 & 45.65 \\
Yes & 75 & 54.35 \\
\hline
\end{tabular}

The characteristics of loan borrowers can be divided into four categories, namely socio-demographic, vehicle, financial ability, and loan related characteristics. Table 2 summarises the socio-demographic characteristics. The majority of respondents were aged from 18 to 41 years and it is only around $10 \%$ of them were aged 50 and above. The respondents were mostly married $(63.77 \%)$ and in terms of ethnicity, more than half were non-Malay (54.35\%). Most respondents stayed in city or town areas $(92.75 \%)$. There were around $44 \%$ of respondents who had the length of stay in an address that was more than 10 years. The Chi-square test of independence was performed between the socio-demographic characteristics and loan default status (Table 2). It was found that the only characteristic significantly related to loan 
default status was area of residence, such that the borrowers from rural residential areas were more likely to default as compared to borrowers in city and town residential areas.

Meanwhile, relating to vehicle related characteristics from Table 3, the purchase price of vehicles was mostly greater than RM60,000, with only around five percent were less than RM60,000. The majority of vehicles were non-Proton $(78.26 \%)$, new $(69.57 \%)$, foreign make (61.59\%), and below 2000cc (88.4\%). The purchase price was found to be significantly related to the loan default status. From Table 3, it appears that the increase of purchase price would increase the likelihood of default. For instance, there is no default for purchase price of less than RM60,000; at the purchase price of RM60,000 to RM69,000, the percentage of default increased to $40 \%$. Other vehicle related characteristics are as reported in Table 3 and these characteristics were found to be independent from the loan default status.

Table 2

Socio-demographic characteristics and loan default

\begin{tabular}{|c|c|c|c|c|c|c|c|c|}
\hline & & \multicolumn{2}{|c|}{ Overall } & \multicolumn{5}{|c|}{ Loan Default } \\
\hline & & & & No & & Yes & & $\begin{array}{l}\text { Chi- } \\
\text { square } \\
\text { test }\end{array}$ \\
\hline \multicolumn{2}{|l|}{ Variable } & Freq. & $\%$ & Freq. & $\%$ & Freq. & $\%$ & $\mathrm{p}$-value \\
\hline \multirow[t]{5}{*}{ age } & $18-25$ & 32 & 23.19 & 14 & 43.75 & 18 & 56.25 & 0.277 \\
\hline & $26-33$ & 38 & 27.54 & 13 & 34.21 & 25 & 65.79 & \\
\hline & $34-41$ & 29 & 21.01 & 13 & 44.83 & 16 & 55.17 & \\
\hline & $42-49$ & 25 & 18.12 & 14 & 56.00 & 11 & 44.00 & \\
\hline & $\begin{array}{l}50 \text { and } \\
\text { above }\end{array}$ & 14 & 10.14 & 9 & 64.29 & 5 & 35.71 & \\
\hline \multirow[t]{2}{*}{$\begin{array}{l}\text { Marital } \\
\text { status }\end{array}$} & $\begin{array}{l}\text { Not } \\
\text { married }\end{array}$ & 50 & 36.23 & 21 & 42.00 & 29 & 58.00 & 0.516 \\
\hline & Married & 88 & 63.77 & 42 & 47.73 & 46 & 52.27 & \\
\hline \multirow[t]{2}{*}{ Ethnicity } & $\begin{array}{l}\text { Non- } \\
\text { Malay }\end{array}$ & 75 & 54.35 & 37 & 49.33 & 38 & 50.67 & 0.344 \\
\hline & Malay & 63 & 45.65 & 26 & 41.27 & 75 & 54.35 & \\
\hline \multirow[t]{2}{*}{ Residential } & City & 58 & 42.03 & 29 & 50.00 & 29 & 50.00 & $0.060^{*}$ \\
\hline & Town & 70 & 50.72 & 33 & 47.14 & 37 & 52.86 & \\
\hline
\end{tabular}


IJMS 24 (1), 73-90 (2017)

\begin{tabular}{|c|c|c|c|c|c|c|c|c|}
\hline & & \multicolumn{2}{|c|}{ Overall } & \multicolumn{5}{|c|}{ Loan Default } \\
\hline & & & & No & & Yes & & $\begin{array}{c}\text { Chi- } \\
\text { square } \\
\text { test }\end{array}$ \\
\hline \multicolumn{2}{|l|}{ Variable } & Freq. & $\%$ & Freq. & $\%$ & Freq. & $\%$ & $\mathrm{p}$-value \\
\hline \multirow{6}{*}{$\begin{array}{l}\text { Length of } \\
\text { stay }\end{array}$} & Rural & 10 & 7.25 & 1 & 10.00 & 9 & 90.00 & \multirow{6}{*}{0.977} \\
\hline & $\begin{array}{l}\text { less } \\
\text { than } 10 \\
\text { years }\end{array}$ & 77 & 55.8 & 34 & 44.16 & 43 & 55.84 & \\
\hline & $\begin{array}{l}11 \text { - } 19 \\
\text { years }\end{array}$ & 14 & 10.14 & 7 & 50.00 & 7 & 50.00 & \\
\hline & $\begin{array}{l}20-29 \\
\text { years }\end{array}$ & 34 & 24.64 & 16 & 47.06 & 18 & 52.94 & \\
\hline & $\begin{array}{l}30-39 \\
\text { years }\end{array}$ & 10 & 7.25 & 5 & 50.00 & 5 & 50.00 & \\
\hline & $\begin{array}{l}40 \text { and } \\
\text { above }\end{array}$ & 3 & 2.17 & 1 & 33.33 & 2 & 66.67 & \\
\hline
\end{tabular}

Note: ${ }^{* * *},{ }^{* *}$, and $*$ represent significant level of $1 \%, 5 \%$ and $10 \%$ respectively.

Table 3

Vehicle related characteristics

\begin{tabular}{|c|c|c|c|c|c|c|c|c|}
\hline & & \multicolumn{2}{|c|}{ Overall } & \multicolumn{5}{|c|}{ Loan Default } \\
\hline & & & & No & & Yes & & $\begin{array}{c}\text { Chi- } \\
\text { square } \\
\text { test }\end{array}$ \\
\hline \multicolumn{2}{|l|}{ Variable } & Freq. & $\%$ & Freq. & $\%$ & Freq. & $\%$ & $\mathrm{p}$-value \\
\hline $\begin{array}{l}\text { Vehicle } \\
\text { price }\end{array}$ & above 90 & 11 & 8.03 & 6 & 54.55 & 5 & 45.45 & $0.001^{* * *}$ \\
\hline \multirow[t]{4}{*}{$\left(\mathrm{RM}^{\prime} 000\right)$} & $80-90$ & 76 & 55.47 & 23 & 30.26 & 53 & 69.74 & \\
\hline & $70-79$ & 28 & 20.44 & 17 & 60.71 & 11 & 39.29 & \\
\hline & $60-69$ & 15 & 10.95 & 9 & 60.00 & 6 & 40.00 & \\
\hline & $\begin{array}{l}\text { less than } \\
60\end{array}$ & 7 & 5.11 & 7 & 100.00 & 0 & 0.00 & \\
\hline \multirow[t]{2}{*}{$\begin{array}{l}\text { Profile of } \\
\text { vehicle }\end{array}$} & Foreign & 85 & 61.59 & 40 & 47.06 & 45 & 52.94 & 0.674 \\
\hline & Malaysia & 53 & 38.41 & 23 & 43.40 & 30 & 56.60 & \\
\hline \multirow[t]{2}{*}{$\begin{array}{l}\text { Types of } \\
\text { vehicle }\end{array}$} & $\begin{array}{l}\text { Non- } \\
\text { Proton }\end{array}$ & 108 & 78.26 & 51 & 47.22 & 57 & 52.78 & 0.482 \\
\hline & Proton & 30 & 21.74 & 12 & 40.00 & 18 & 60.00 & \\
\hline
\end{tabular}


IJMS 24 (1), 73-90 (2017)

\begin{tabular}{|c|c|c|c|c|c|c|c|c|}
\hline & & \multicolumn{2}{|c|}{ Overall } & \multicolumn{5}{|c|}{ Loan Default } \\
\hline & & & & No & & Yes & & $\begin{array}{c}\text { Chi- } \\
\text { square } \\
\text { test }\end{array}$ \\
\hline \multicolumn{2}{|l|}{ Variable } & Freq. & $\%$ & Freq. & $\%$ & Freq. & $\%$ & $\mathrm{p}$-value \\
\hline \multirow[t]{2}{*}{ Condition } & $\begin{array}{l}\text { Used/ } \\
\text { Recond. }\end{array}$ & 42 & 30.43 & 19 & 45.24 & 23 & 54.76 & 0.948 \\
\hline & New & 96 & 69.57 & 44 & 45.83 & 52 & 54.17 & \\
\hline \multirow[t]{5}{*}{$\begin{array}{l}\text { Capacity } \\
\text { (cc) }\end{array}$} & $\begin{array}{l}\text { less than } \\
1000\end{array}$ & 11 & 7.97 & 5 & 45.45 & 6 & 54.55 & 0.992 \\
\hline & $\begin{array}{l}1001 \text { cc - } \\
1500 \text { cc }\end{array}$ & 46 & 33.33 & 20 & 43.48 & 26 & 56.52 & \\
\hline & $\begin{array}{l}1501 \mathrm{cc}- \\
2000 \mathrm{cc}\end{array}$ & 65 & 47.10 & 31 & 47.69 & 34 & 52.31 & \\
\hline & $\begin{array}{l}2001 \mathrm{cc}- \\
2500 \mathrm{cc}\end{array}$ & 14 & 10.14 & 6 & 42.86 & 8 & 57.14 & \\
\hline & $\begin{array}{l}2501 \\
\text { cc and } \\
\text { above }\end{array}$ & 2 & 1.45 & 1 & 50.00 & 1 & 50.00 & \\
\hline
\end{tabular}

Note: ${ }^{* * *}, * *$ and $*$ represent significant level of $1 \%, 5 \%$ and $10 \%$ respectively.

In terms of financial ability of respondents from Table 4, more than half of them were not home owners (53.62\%) and a third of them had a length of stay in a place of residence for more than 10 years $(30.15 \%)$. The majority of respondents were salaried employees $(66.67 \%)$, and in the private sector $(76.81 \%)$. More than half of the respondents were earning less than RM5,000 per month and only around $10 \%$ of them were earning more than RM10,000 per month. For those who were married, the majority of their spouses were earning less than RM4,000 per month. There were around $20 \%$ of respondents who had other loans and as expected, almost all respondents' repayment analysis (ratio of total instalment to gross income) were less than 60. Results of the Chi-square test of independence revealed that it is only the length of stay that was significantly related to loan default status, such that longer length of stay in an address is associated with lower percentage of default.

Table 5 presents the loan related characteristics. It revealed that the majority of loans amounted to RM100,000 and below (74.64\%) and with tenure of more than 60 months $(86.23 \%)$. The interest rate charged were mostly in the range of $1 \%$ to $4.99 \%$. It was only a handful of respondents that were charged with interest of greater than $5 \%$. More than half the respondents had paid monthly instalments of more than RM500 (59.42\%) and without guarantor (58.7\%). However, the loan 
IJMS 24 (1), 73-90 (2017)

related characteristics were found to be not significantly associated with loan default status as shown by the p-values (Chi-squared test of independence) that were greater than 0.10 .

Table 4

Financial ability related characteristics and loan default

\begin{tabular}{|c|c|c|c|c|c|c|c|c|}
\hline & & \multicolumn{2}{|c|}{ Overall } & \multicolumn{5}{|c|}{ Loan Default } \\
\hline & & & & No & & Yes & & $\begin{array}{l}\text { Chi- } \\
\text { square } \\
\text { test }\end{array}$ \\
\hline \multicolumn{2}{|l|}{ Variable } & Freq. & $\%$ & Freq. & $\%$ & Freq. & $\%$ & $\mathrm{p}$-value \\
\hline \multirow[t]{2}{*}{ Residential } & Rent/others & 74 & 53.62 & 33 & 44.59 & 41 & 55.41 & 0.789 \\
\hline & Owned & 64 & 46.38 & 30 & 46.88 & 34 & 53.13 & \\
\hline \multirow[t]{4}{*}{$\begin{array}{l}\text { Length of } \\
\text { stay }\end{array}$} & $\begin{array}{l}\text { less than } 10 \\
\text { years }\end{array}$ & 95 & 69.85 & 37 & 38.95 & 58 & 61.05 & $0.074^{*}$ \\
\hline & 11 - 19 years & 26 & 19.12 & 15 & 57.69 & 11 & 42.31 & \\
\hline & 20 - 29 years & 13 & 9.56 & 8 & 61.54 & 5 & 38.46 & \\
\hline & Others & 2 & 1.47 & 2 & 100.00 & 0 & 0.00 & \\
\hline \multirow[t]{2}{*}{ Employment } & Salaried & 92 & 66.67 & 45 & 48.91 & 47 & 51.09 & 0.277 \\
\hline & Self & 46 & 33.33 & 18 & 39.13 & 28 & 60.87 & \\
\hline \multirow[t]{2}{*}{ Sector } & Government & 32 & 23.19 & 16 & 50.00 & 16 & 50.00 & 0.573 \\
\hline & Private & 106 & 76.81 & 47 & 44.34 & 59 & 55.66 & \\
\hline \multirow{5}{*}{$\begin{array}{l}\text { Borrower's } \\
\text { gross } \\
\text { income } \\
(\mathrm{RM})\end{array}$} & $\begin{array}{l}\text { less than } \\
2,000\end{array}$ & 25 & 18.12 & 12 & 48.00 & 13 & 52.00 & 0.876 \\
\hline & $2,000-4,999$ & 61 & 44.20 & 28 & 45.90 & 33 & 54.10 & \\
\hline & $5,000-6,999$ & 20 & 14.49 & 10 & 50.00 & 10 & 50.00 & \\
\hline & 7,000 - 9,999 & 12 & 8.70 & 6 & 50.00 & 6 & 50.00 & \\
\hline & $\begin{array}{l}10,000 \text { and } \\
\text { above }\end{array}$ & 20 & 14.49 & 7 & 35.00 & 13 & 65.00 & \\
\hline \multirow{4}{*}{$\begin{array}{l}\text { Spouse's } \\
\text { gross } \\
\text { income } \\
(\mathrm{RM})\end{array}$} & $\begin{array}{l}\text { less than } \\
1000\end{array}$ & 1 & 3.70 & 0 & 0.00 & 1 & 100.00 & 0.485 \\
\hline & $1001-2000$ & 10 & 37.04 & 3 & 30.00 & 7 & 70.00 & \\
\hline & $2001-3000$ & 7 & 25.93 & 4 & 57.14 & 3 & 42.86 & \\
\hline & $3001-4000$ & 1 & 3.70 & 1 & 100.00 & 0 & 0.00 & \\
\hline
\end{tabular}


IJMS 24 (1), 73-90 (2017)

\begin{tabular}{|c|c|c|c|c|c|c|c|c|}
\hline & & \multicolumn{2}{|c|}{ Overall } & \multicolumn{5}{|c|}{ Loan Default } \\
\hline & & & & No & & Yes & & $\begin{array}{l}\text { Chi- } \\
\text { square } \\
\text { test }\end{array}$ \\
\hline \multirow[t]{2}{*}{ Variable } & & Freq. & $\%$ & Freq. & $\%$ & Freq. & $\%$ & p-value \\
\hline & $\begin{array}{l}4000 \text { and } \\
\text { above }\end{array}$ & 8 & 29.63 & 4 & 50.00 & 4 & 50.00 & \\
\hline \multirow[t]{2}{*}{ Other loan? } & Yes & 28 & 20.29 & 14 & 50.00 & 14 & 50.00 & 0.605 \\
\hline & No & 110 & 79.71 & 49 & 44.55 & 61 & 55.42 & \\
\hline \multirow[t]{5}{*}{$\begin{array}{l}\text { Repayment } \\
\text { analysis }\end{array}$} & $0-15$ & 36 & 26.09 & 12 & 33.33 & 24 & 66.67 & 0.315 \\
\hline & $16-30$ & 58 & 42.03 & 26 & 44.83 & 32 & 55.17 & \\
\hline & $31-45$ & 17 & 12.32 & 9 & 52.94 & 8 & 47.06 & \\
\hline & $41-60$ & 16 & 11.59 & 9 & 56.25 & 7 & 43.75 & \\
\hline & $\begin{array}{l}61 \text { and } \\
\text { above }\end{array}$ & 11 & 7.97 & 7 & 63.64 & 4 & 36.36 & \\
\hline
\end{tabular}

Note: ${ }^{* *},{ }^{* *}$, and ${ }^{*}$ represent significant level of $1 \%, 5 \%$ and $10 \%$ respectively.

\section{Table 5}

Loan related characteristics and loan default

\begin{tabular}{|c|c|c|c|c|c|c|c|c|}
\hline & & \multicolumn{2}{|c|}{ Overall } & \multicolumn{5}{|c|}{ Loan Default } \\
\hline & & & & No & & Yes & & $\begin{array}{l}\text { Chi- } \\
\text { square } \\
\text { test }\end{array}$ \\
\hline Variable & & Freq. & $\%$ & Freq. & $\%$ & Freq. & $\%$ & $\mathrm{p}$-value \\
\hline \multirow[t]{5}{*}{$\begin{array}{l}\text { Loan } \\
\text { amount } \\
(\mathrm{RM})\end{array}$} & $\begin{array}{l}\text { less than } \\
50,000\end{array}$ & 52 & 37.68 & 24 & 46.15 & 28 & 53.85 & 0.538 \\
\hline & $\begin{array}{l}50,001- \\
100,000\end{array}$ & 51 & 36.96 & 25 & 49.02 & 26 & 50.98 & \\
\hline & $\begin{array}{l}100,001 \text { - } \\
150,000\end{array}$ & 23 & 16.67 & 11 & 47.83 & 12 & 52.17 & \\
\hline & $\begin{array}{l}150,001- \\
200,000\end{array}$ & 7 & 5.07 & 1 & 14.29 & 6 & 85.71 & \\
\hline & $\begin{array}{l}200,000 \\
\text { and } \\
\text { above }\end{array}$ & 5 & 3.62 & 2 & 40.00 & 3 & 60.00 & \\
\hline Tenure & $\begin{array}{l}\text { less } \\
\text { than } 24 \\
\text { months }\end{array}$ & 1 & 0.72 & 1 & 100.00 & 0 & 0.00 & 0.141 \\
\hline
\end{tabular}

(continued) 
IJMS 24 (1), 73-90 (2017)

\begin{tabular}{|c|c|c|c|c|c|c|c|c|}
\hline & & \multicolumn{2}{|c|}{ Overall } & \multicolumn{5}{|c|}{ Loan Default } \\
\hline & & & & No & & Yes & & $\begin{array}{c}\text { Chi- } \\
\text { square } \\
\text { test }\end{array}$ \\
\hline \multirow[t]{5}{*}{ Variable } & & Freq. & $\%$ & Freq. & $\%$ & Freq. & $\%$ & $\mathrm{p}$-value \\
\hline & $\begin{array}{l}25 \\
\text { months } \\
\text { to } 48 \\
\text { months }\end{array}$ & 5 & 3.62 & 4 & 80.00 & 1 & 20.00 & \\
\hline & $\begin{array}{l}49 \\
\text { months } \\
\text { to } 60 \\
\text { months }\end{array}$ & 13 & 9.42 & 7 & 53.85 & 6 & 46.15 & \\
\hline & $\begin{array}{l}61 \\
\text { months } \\
\text { to } 84 \\
\text { months }\end{array}$ & 35 & 25.36 & 19 & 54.29 & 16 & 45.71 & \\
\hline & $\begin{array}{l}\text { more } \\
\text { than } 85 \\
\text { months }\end{array}$ & 84 & 60.87 & 32 & 38.10 & 52 & 61.90 & \\
\hline \multirow[t]{4}{*}{ Interest } & $\begin{array}{l}1 \%-2.99 \\
\%\end{array}$ & 62 & 44.93 & 34 & 54.84 & 28 & 45.16 & 0.210 \\
\hline & $\begin{array}{l}3 \%-4.99 \\
\%\end{array}$ & 73 & 52.90 & 28 & 38.36 & 45 & 61.64 & \\
\hline & $\begin{array}{l}5 \%- \\
6.99 \%\end{array}$ & 2 & 1.45 & 1 & 50.00 & 1 & 50.00 & \\
\hline & $\begin{array}{l}7 \% \text { and } \\
\text { above }\end{array}$ & 1 & 0.72 & 0 & 0.00 & 1 & 100.00 & \\
\hline \multirow[t]{5}{*}{$\begin{array}{l}\text { Instalment } \\
\text { (RM) }\end{array}$} & $\begin{array}{l}\text { less than } \\
200\end{array}$ & 25 & 18.12 & 11 & 44.00 & 14 & 56.00 & 0.127 \\
\hline & $201-300$ & 12 & 8.70 & 3 & 25.00 & 9 & 75.00 & \\
\hline & $301-400$ & 15 & 10.87 & 6 & 40.00 & 9 & 60.00 & \\
\hline & $401-500$ & 4 & 2.90 & 0 & 0.00 & 4 & 100.00 & \\
\hline & $\begin{array}{l}501 \text { and } \\
\text { above }\end{array}$ & 82 & 59.42 & 43 & 52.44 & 39 & 47.56 & \\
\hline \multirow[t]{2}{*}{ Guarantor? } & No & 81 & 58.70 & 33 & 40.74 & 48 & 59.26 & 0.167 \\
\hline & Yes & 57 & 41.30 & 30 & 52.63 & 27 & 47.37 & \\
\hline
\end{tabular}

Note: ${ }^{* * *},{ }^{* *}$, and ${ }^{*}$ represent significant level of $1 \%, 5 \%$ and $10 \%$ respectively.

In short, the descriptive statistics and Chi-square test of independence showed that there were only a few variables (residential areas, vehicle price, and length of stay in current home) closely associated with loan default status. Nevertheless, it is important to note that since the descriptive statistics analysis and Chi-square test were performed without controlling the influences of other variables, the results would be largely inconclusive at this point. Thus, in the following 
section, logit models shall be estimated which allows the control of influences of other variables.

\section{The estimated logit models}

Five logit models were estimated using different sets of independent variables: socio-demographic characteristics (Model 1), vehicle related characteristics (Model 2), financial ability related characteristics (Model 3), loan related characteristics (Model 4), and all characteristics combined (Model 5). Table 6 presents these estimated logit models. In terms of goodness of fit, as expected, Model 5 which includes all independent variables was the best fit model with a pseudo $R^{2}$ of 0.344 . The overall fit test was found to be significant with $p$-value of almost zero. The other estimated logit models (Model 1-4) were found to be significant at least $10 \%$ level in their overall fit tests, and with pseudo $R^{2}$ of at least 0.05 .

Comparing the Models 1-4, it was found that loan characteristics model (Model 4) had the highest value of pseudo $R^{2}(0.135)$ and overall fit ( $p$-value of 0.002). This was followed by Model 2 (vehicle characteristics variables), Model 3 (financial ability characteristics), and Model 1 (socio-demographic characteristics). Thus, among the four, loan characteristics variables had the highest explanatory power on the loan default.

Table 6

The estimated logit models

\begin{tabular}{lccccc}
\hline & 1 & 2 & 3 & 4 & 5 \\
\hline Variable & Socio-D & Vehicle & Financial & Loan & ALL \\
\hline Age & Coef. & Coef. & Coef. & Coef. & Coef. \\
Married $^{2}$ & -0.270 & - & - & - & 0.041 \\
City $^{2}$ & 0.205 & - & - & - & -0.694 \\
Town $^{2}$ & $-2.358^{* * *}$ & - & - & - & $-5.039^{* * *}$ \\
Length of stay $^{2}$ & $-2.193^{* *}$ & - & - & - & $-5.082^{* * *}$ \\
Malay $^{2}$ & -0.113 & - & - & - & -0.151 \\
\hline & 0.277 & - & - & - & 0.585 \\
\hline
\end{tabular}


IJMS 24 (1), 73-90 (2017)

\begin{tabular}{|c|c|c|c|c|c|}
\hline & 1 & 2 & 3 & 4 & 5 \\
\hline & Socio-D & Vehicle & Financial & Loan & ALL \\
\hline Variable & Coef. & Coef. & Coef. & Coef. & Coef. \\
\hline Purchase price & - & 1.508 & - & - & $2.624^{* *}$ \\
\hline $\begin{array}{l}\text { Squared } \\
\text { Purchase price }\end{array}$ & - & $-0.394^{* *}$ & - & - & $-0.622^{* * * *}$ \\
\hline $\begin{array}{l}\text { Malaysia } \\
\text { vehicle }^{3}\end{array}$ & - & -0.221 & - & - & -1.133 \\
\hline Proton $^{3}$ & - & 0.241 & - & - & 0.687 \\
\hline New Condition ${ }^{3}$ & - & -0.184 & - & - & 0.324 \\
\hline $\begin{array}{l}\text { Capacity of } \\
\text { vehicle }\end{array}$ & - & -0.034 & - & - & -0.104 \\
\hline $\begin{array}{l}\text { Own } \\
\text { residential }^{4}\end{array}$ & - & - & 0.502 & - & 0.817 \\
\hline Self employed ${ }^{4}$ & - & - & 0.472 & - & 0.518 \\
\hline Private sector ${ }^{4}$ & - & - & -0.264 & - & -0.151 \\
\hline $\begin{array}{l}\text { Length of } \\
\text { service }\end{array}$ & - & - & -1.101 & - & $-3.485^{* * *}$ \\
\hline $\begin{array}{l}\text { Squared Length } \\
\text { of service }\end{array}$ & - & - & 0.068 & - & $0.554^{* * *}$ \\
\hline $\begin{array}{l}\text { Total gross } \\
\text { income }\end{array}$ & - & - & 0.107 & - & 0.443 \\
\hline $\begin{array}{l}\text { Spouse gross } \\
\text { income }\end{array}$ & - & - & 0.073 & - & 0.274 \\
\hline Other loan & - & - & -0.083 & - & 0.062 \\
\hline $\begin{array}{l}\text { Repayment } \\
\text { analysis }^{5}\end{array}$ & - & - & $-0.344^{* *}$ & - & -0.198 \\
\hline New customer ${ }^{6}$ & - & - & - & $1.491^{* * *}$ & $1.780^{* *}$ \\
\hline Loan amount & - & - & - & $0.388^{*}$ & 0.042 \\
\hline Tenure of loan & - & - & - & $0.496^{* *}$ & 0.137 \\
\hline Interest rate & - & - & - & $0.851^{* *}$ & $1.139^{* *}$ \\
\hline Instalment & - & - & - & -0.208 & -0.159 \\
\hline Guarantor? & - & - & - & $-0.809^{* *}$ & $-1.749^{* *}$ \\
\hline Constant & $2.997^{* * *}$ & -0.566 & $1.900^{* *}$ & $-5.096^{* * * *}$ & 2.096 \\
\hline $\begin{array}{l}\text { Overall fit } \\
\text { (p-value) }\end{array}$ & $0.067^{*}$ & $0.052^{*}$ & $0.048^{* *}$ & $0.002^{* * *}$ & $0.001^{* * *}$ \\
\hline $\begin{array}{l}\text { Pseudo } \\
\text { R-squared }\end{array}$ & 0.057 & 0.091 & 0.081 & 0.135 & 0.344 \\
\hline
\end{tabular}

Note:

1. ${ }^{* * *},{ }^{* *}$, and ${ }^{*}$ represent significant level of $1 \%, 5 \%$ and $10 \%$ respectively. 
2. Comparison group: Married (not married); City/Town (Rural); Malay (Non-Malay).

3. Comparison group: Malaysia vehicle (foreign); Proton (Non-Proton); New Condition (Used).

4. Comparison group: Own residential (rent); self-employed (salaried employee); Private sector (government).

5. Repayment analysis $=$ Financial commitment/Gross income .

6. Comparison group: New customer (existing).

In general, from Table 6 (Model 5), it can be clearly observed that the significant determinants of loan default are: areas of residence, vehicle purchase price, length of service, existing relationship with bank, interest rate, and available guarantor. Specifically, in terms of socio-demographic variables, borrowers who reside in rural areas are more likely to be default compared to those who are in city or town areas. This result is in line with Tanninen (2013) who found that smaller cities are associated with payment difficulties. This negative relationship could be due to borrowers from rural areas tend to have older cars as can be easily observed in the case of Malaysia. From vehicle characteristics, the purchase price was found to have a significant and U-shape quadratic effect on probability of loan default. ${ }^{3}$ Thus, the increase of purchase price will decrease the underlying tendency of being default initially until the price of RM80,000-RM90,000, ${ }^{4}$ where the increase of purchase price will increase the tendency of default at lower rates. This non-linear effect of purchase price revealed that vehicle with lower purchase price will have lower risk of default until RM80,000. This finding of strong and significant impact of car price is consistent with previous research, such as Tanninen (2013). This is not surprising because vehicle price could influence the repayment burden, especially at higher prices.

Similarly, the length of employment service of borrowers had a significant and $\mathrm{u}$-shape quadratic effect of probability of default. The increase of length of service of borrowers will decrease the underlying tendency of being default initially, until the 20-29 years of service; the increase of length of service will increase the tendency of default. This non-linear effect of length of service suggested that borrowers with long length of service would help in reducing the probability of default until the length of service with current employer exceeds 20 years. This was consistent with the findings of Moffatt (2003), who

\footnotetext{
3 Since the variable of purchase price is in five categories of reverse ordered of amount: $1=$ above $90,2=80-90,3=70-79,4=60-69$ and $5=$ less than 60 (see Table 3 ).

$4-\left(2.624 /\left(2^{*}(-0.622)\right)\right)=2.111 \approx 2$, i.e., $2=R M 80,000$ to RM90,000
} 
found that seniors have more chances to lose their jobs and thus, increase the probability of default. In terms of loan characteristics, it was found that borrowers who are new to the bank, borrowers who have been charged with higher interest rates, and borrowers without a guarantor, all have higher probability of default as compared to those who are otherwise (existing borrowers, charged with lower interest rate and with guarantor). This finding of significance of interest rate seems to be contradictory with previous studies, such as Goriunov and Venzhyk (2007) who found that interest rates has no significant impact in the presence of variables that capture the repayment cost (for instance, loan amount and monthly instalment). Nevertheless, it is important to note that the insignificance of interest rate might be due to the low variation of interest rates. In the present study, the interest rates have high variation (ranging from $1 \%$ to more than $7 \%$ ). This enables the researchers to estimate the impact on interest rate on probability of car loan default.

\section{Conclusion}

Using a simple random sample of 138 car loan borrowers from an established bank in Malaysia, this paper estimated the determinants of loan default. More than half of borrowers were found to be default, i.e., default at least for two monthly instalments. This revealed the seriousness of car loan default in Malaysia. Overall, the econometrics analysis showed that loan related characteristics are the most important determinants of probability of default, compared to sociodemographic, financial ability, and vehicle related characteristics. Interestingly, with high variation, the interest rate factor was found to be significant. This result might offer a partial explanation why the interest rate was found insignificant in previous studies; they employed the variable of interest rate with low variation. In addition, the result of the present study suggested that effect of purchase price is non-linear. Overall, the results revealed that the significant determinants of loan default are areas of residence, vehicle purchase price, length of service, existing relationship with bank, interest rate, and available guarantor. Borrowers who are more likely to be default are those whose residence is in rural areas, higher vehicle purchase price, longer employment services, borrower new to the bank, loan charged with high interest rate, and without a guarantor. The findings are subjected to one important caveat. Although with a random sample, the present study is mainly exploratory due to the small sample size. Future studies are suggested to use a larger and representative sample to explore further into this contention. 


\section{Acknowledgment}

We would like to thank Universiti Utara Malaysia for providing financial support for this study through its PBIT research grant (Code S/O: 12617). Thanks are also due to the anonymous reviewer of IJMS whose comments have improved this paper substantially.

\section{References}

Alfaro, R. \& Gallardo, N. (2012). The determinants of household debt default. Revista de Analisis Economico, 27(1), 55-70.

Avery, R., Calem, P. \& Canner, G. (2004). Consumer credit scoring: do situational circumstances matter? Journal of Banking and Finance, 28(4), 835-856.

Awotwi, K.E. (2011). Estimation of the probability of default of consumer credit in Ghana: case study of an international bank. Unpublish Master thesis, Department of Mathematics, Kwame Nkrumah University of Science and Technology Kumasi, Ghana.

Chu, K. (2014). Credit-Scoring firms take aim at Malaysia. The Wall Street Journal. Online Article, retrieved on Aug 31, 2015 from http://www.wsj.com/articles/credit-scoring-firms-take-aim-atmalaysia-1416861241

Everything you should know about CCRIS. (2014). Loanstreet. Online article. retrieved on Aug 31, 2015 from http://loanstreet.com. my/learning-centre/everything-about-ccris

Goriunov, D. \& Venzhyk, K. (2007). Loan default prediction in Ukrainian retail banking. Working Paper No. 13/07E, Economics Education and Research Consortium (RERC), Sweden.

Gurny, P. \& Gurny, M. (2013). Comparison of credit scoring models on probability of default estimation for US bank. Prague Economic Papers, 2, 163-181.

Halim, S. (2014). The rising debt numbers in Malaysia. The Edge Online Newspaper, retrieved on Aug 31, 2015 from http://www. edgy.my/rising-debt-numbers-malaysia

Horkko, M. (2010). The determinants of default in consumer credit market. Unpublish Master thesis, School of Economics, Aalto University, Finland.

Kong, S. H. (2014). Credit squeeze hits auto industry. The Sun Daily, September 2, 2014, retrieved on Aug 31, 2015 from http://www. thesundaily.my/news/1158234

Moffatt, P. (2003). Hurdle models of loan default. August 2003. 
IJMS 24 (1), 73-90 (2017)

Okumu, A.W., Mwalili, S., \& Mwita, P. (2012). Modelling Credit Risk for Personal Loans Using Product-Limit Estimator. International Journal of Financial Research, 3(1), 22-32.

Selvarani, P. (2011). Driven to bankruptcy. New Straits Times. Online news November 13, 2011, retrieved on Aug 31, 2015 from http:// www2.nst.com.my/top-news/driven-to-bankruptcy-1.5124

Sharma, M. \& Zeller, M. (1997). Repayment performance in groupbased credit programs in Bangladesh: An empirical analysis. World Development, 25(10), 1731-1742.

Stavins, J. (2000). Credit Card Borrowing, Delinquency, and Personal Bankruptcy. Federal Reserve Bank of Boston. New England Economic Review, 15-30. Retrieved on September 9, 2015 from http://www.bos.frb.org/economic/neer/neer2000/neer400b.pdf

Tang, T. C. (2003). Bank lending and economic growth in Malaysia: Revisited. International Journal of Management Studies, 10(1), 6987.

Tanninen, M. (2013). Determinants of credit risk in secured loans Evidence from the auto loan industry. Unpublish Master thesis, School of Business, Lappeenranta University of Technology, Finland. 